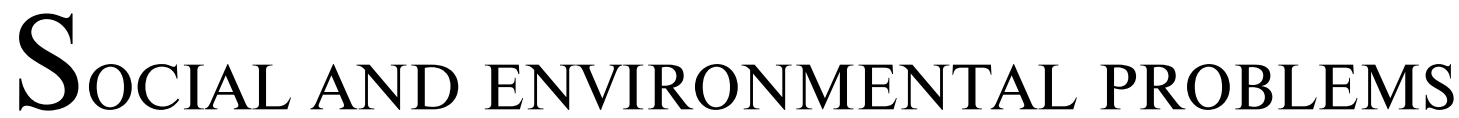 OF SUSTAINABLE DEVELOPMENT
}

\section{ЭКОАОГИЧЕСКАЯ БЕЗОПАСНОСТЬ В ОБЩЕСТВЕ РИСКА}

\author{
T. В. МИШАТкинА ${ }^{1)}$ \\ ${ }^{1)}$ Международный государственный институт имени А. Д. Сахарова, \\ Белорусский государственный университет, \\ ул. Долгобродская, 23/1, 220070, г. Минск, Беларусь
}

Современная ситуация общества риска, для которого характерны новые реалии - от глобального изменения климата до пандемии COVID-2019, которая несет опасность отдельному индивидууму на микроуровне - поставила вопрос о необходимости обращения к новой парадигме постгуманизма: дополнению однозначной оптимистической ориентации на устойчивое развитие более пессимистической, но и более актуально-реалистичной стратегией выживания, которой соответствует новая форма экологической этики - экстремальная этика.

Ключевые слова: общество риска; цивилизационный риск; опасность; экологическая угроза; эвристика страха; стратегия выживания; экстремальная этика.

Благодарность. Исследование проведено при финансовой поддержке Фонда фундаментальных исследований Национальной академии наук Республики Беларусь, проект № Б15МЛД-029.

\section{Образец цитирования:}

Мишаткина ТВ. Экологическая безопасность в обществе риска. Журнал Белорусского государственного университета. Экология. 2021;1:4-14.

https://doi.org//10.46646/2521-683X/2021-1-4-14
For citation:

Mishatkina TV. Ecological security in risk society. Journal of the Belarusian State University. Ecology. 2021;1:4-14. Russian. https://doi.org//10.46646/2521-683X/2021-1-4-14

\section{A в тор :}

Татьяна Викторовна Мишаткина - кандидат философских наук, доцент; ведущий научный сотрудник научно-исследовательского сектора.

\section{Author:}

Tatyana V. Mishatkina, $\mathrm{PhD}$ (philosophy), docent; leading researcher at the scientific-and-research department. mtv_2013@tut.by 


\title{
ECOLOGICAL SECURITY IN RISK SOCIETY
}

\author{
T. V. MISHATKINA \\ anternational Sakharov Environmental Institute, Belarusian State University, \\ 23/1 Daŭhabrodskaja Street, Minsk 220070, Belarus
}

The current situation in the risk society characterised by the new realities (from the global climate change to the pandemic penetration of a new virus in the human body) has brought to light the need to turn to a new paradigm of posthumanism, i.e. supplementing the unequivocal optimistic orientation on sustainable development with a more pessimistic, but also more topical and realistic, survival strategy aligned with extreme ethics, a new for ecological security in risk society.

Keywords: risk society; civilisation risk; danger; ecological threat; heuristics of fear; survival strategy;extreme ethics.

Acknowledgments. This work was sponsored by the Belarusian Republican Foundation for Fundamental Research, Project Б15МЛД-029.

\section{Введение}

Современные сообщества переживают период глубоких цивилизационных преобразований. Эти перемены фиксируются в понятиях «информационное общество», «постиндустриальное общество», «сетевое общество», «постчеловеческое общество» и др. Но, по мнению одного из наиболее влиятельных немецких социологов Ульриха Бека, на самом деле намечается будущее, реальность которого наиболее адекватно может быть обозначена как общество риска. Для него характерны новые реалии, предполагающие принципиально новый стиль мышления, отношения к жизни и ее ценностям. Цель статьи - выявить и проанализировать их специфику и особенности, ведущие к формированию новой энвайронментальной парадигмы как необходимого условия устойчивого развития и стратегии выживания человечества в обществе риска.

\section{Общество риска и экологическая безопасность}

Риски - не изобретение нового времени. Они существовали всегда: когда кто-то пускался в путь, чтобы открывать новые страны и части света, или проводил на себе научный эксперимент. Однако, как утверждает У. Бек, «это был личный риск, а не глобальная угроза для всего человечества, которая возникает при расщеплении атомного ядра или складировании ядерных отходов. Слово “риск” тогда имело оттенок мужества, приключения, а не возможного самоуничтожения жизни на Земле» [1].

Другое принципиальное отличие состоит в том, что в предшествующую эпоху риск рассматривался как результат недостаточного развития технологий и научных знаний. Мышление людей находилось во власти диктатуры бедности. Как пишет Бек, «движущую силу классового общества можно было выразить одной фразой: “Я хочу есть!”». Преодолеть этот недостаток должно было производство материальных благ - богатства. Поэтому магистральный путь уменьшения цивилизационных рисков виделся в научном познании, создании новейших технологий и развитии производства. К концу ушедшего века ситуация в индустриально развитых странах качественно изменилась. Риски, с которыми все больше имеет дело человек, формируются не недостатком, а избыточностью технологического и научного прогресса. Активно формируется новый тип социальности - общество риска, «движущая сила которого выражается фразой: “Я боюсь!” Место общности нужды занимает общность страха, который маркирует в этом смысле нашу эпоху» [2].

Еще в начале 1960-х гг. философ Г. Йонас предупреждал, что в эпоху надвигающейся экологической катастрофы негативным основанием нового типа солидарности и ответственности становится эвристика страха [2]. К концу века «страх» становится мощным политическим инструментом, которым пользуются не только зеленые партии и группы, но и все остальные - от представителей традиционного истеблишмента до экстремистских групп. Экологический страх стал фактором политики, стимулом развития новых типов производства. Он составляет содержание нового типа мифологии, в которой на место злых духов встают такие силы, как облучение, загрязнение, генетически модифицированные продукты, повышенное содержание в продуктах сахара, соли, холестерина и т.д.

Подтверждением концепции Г. Йонаса об эвристике страха стала и ситуация, сложившаяся в мире вокруг пандемии коронавируса (COVID-2019), когда страх, основанный на научной неопределенности и низком уровне общественного сознания, превратился в панику - одно из самых опасных социальных явлений. Страх реально стал определять социальную политику и обыденное поведение населения, сопровождаясь еще более долгосрочным ощущением тревожности.

В этих условиях риск из отслеживаемых, измеряемых и контролируемых побочных последствий научно-технической деятельности оборачивается неисчерпаемым источником нового класса потребностей, 
новых угроз, которые ранее не существовали или не принимались в расчет. Например, фильтры, очищающие воду для питья от вредных веществ, сами выделяют в эту «очищенную» воду вещества, способные вызвать в организме человека негативные явления.

При этом если материальными благами (богатством), которые получает социум, можно владеть, распоряжаться им по своему усмотрению, то рисками владеть нельзя, «риски нас настигают». Богатство, создание которого порождает риски и угрозы, можно пытаться уберечь за оградой дома, за стенами города или рубежами национальных границ. Риск же делает эти границы несуществующими. Богатство иерархично, риск (например, смог) даже не демократичен, он тоталитарно влияет на каждого. Озоновые дыры, глобальное потепление и COVID-2019 - это риски и для индустриально развитых стран, и для слаборазвитых. Выбросы автотранспорта, сбросы промышленных отходов в реки, последствия технологических катастроф типа чернобыльской «не замечают» национальных границ, не признают различий между богатыми и бедными - они угрожают всем и каждому.

В системе социально-экономических институтов общества риска особую роль играет наука, которая трояко участвует в возникновении и углублении цивилизационных опасностей и рисков. Во-первых, она оказывается со-причиной главных цивилизационных антропогенных рисков, во-вторых - становится их признанным диагностом, «органом восприятия», поскольку лишь наука в силах распознать риски вирусов, пестицидов, холестерина, сахара, нитратов и т. д., в-третьих, наука призвана разрабатывать новые, более совершенные средства защиты от них, т.е. она создает предпосылки для преодоления угроз, возникших по ее же вине.

Сегодня совершенно дикой природы как бы нет - все является специфическим продуктом научно-технического, экономико-социального прогресса. В наводнениях, засухах, болезнях - во всех экзистенциальных угрозах обнаруживается присутствие человека. Ошибки и риски становятся новыми источниками научной экспансии и технического прогресса. При этом если во внутреннем пространстве науки сохранялись и обсуждались какие-то сомнения, то одновременно «вовне» происходило сокрытие рисков от общественности.

В обществе риска происходит рефлексивное замыкание научного сомнения на саму научную деятельность. Однако обнаруженный обществом циивилизачионный риск, прежде всего в форме экологической yгрозы, принципиально не наблюдаем монодисциплинарным взглядом, с позиций одной науки, когда ученый - эксперт в своей области - мог дать ответ на вопросы: «что происходит?», «почему?» и «что делать?». В новой ситуации обнаруживается явная недостаточность монодисциплинарного подхода. Цивилизационный риск обнаруживается только мультидисциплинарно, совокупными усилиями многих наук.

Правда, при этом одна наука сталкивается с другой, а значит, со скепсисом и пренебрежением, которые они способны высказать по отношению друг к другу. В результате такого взаимодействия набора различных наук, процедуры восприятия, осознания и оценки риска осуществляются не в некотором «научном центре», претендующем на полноту знания и автономность принимаемых решений, а в коммуникативном процессе в сети конфликтующих источников в условиях неполной и недостаточно научной информации.

Пространство коммуникативного и решающего взаимодействия в процедуре оценки цивилизационных/ экологических рисков выпадает из ведения науки в привычном понимании, и ее место в оценке рисков занимает общество. Причем, как показывают исследования, чем ниже уровень социально-экономического развития общества, тем меньше осознаются экологические риски, и тем слабее их осознание мотивирует поведение граждан.

Такова в общих чертах концепция общества риска, открывающая новый подход к пониманию специфики современной экологической ситуации [3]. В Беларуси политика и необходимость эколого-этической и правовой регуляции в целях обеспечения эко- и биобезопасности определяется рядом дополнительных конкретных обстоятельств. В частности, это проблемы экологической и радиационной безопасности, связанные со строительством и эксплуатацией Белорусской АЭС, нерешенные проблемы социальной и морально-психологической реабилитации населения, пострадавшего от Чернобыльской катастрофы, поиск и использование альтернативных и возобновляемых источников энергии, необходимость обеспечения биологической безопасности, связанной с бурным развитием науки и современных биотехнологий, проблемы политической, правовой и этической регуляции безопасной медицины и экологии человека.

\section{Опасности и риски антропогенных воздействий на экологическую безопасность и биоразнообразие}

В целях обеспечения безопасности отдельного индивидуума и общества в целом, используется понятие «концепции риска», которое является эффективным инструментом обоснования управленческих решений в области обеспечения экологической безопасности, поскольку угрозы для нее имеются всегда, а любые мероприятия, направленные на их предотвращение, способны лишь уменьшить риск, но не могут исключить его в принципе. Риски, угрозы, опасности невозможно полностью исключить из процесса развития экосистем, бытия человека, общества и природы. Источником их может оказаться любая из 
подсистем социоприродной экосистемы - неживая природа (например, землетрясение или цунами); живая природа (например, появление того или иного вируса), «вторая природа» - культура, создаваемая людьми (антропогенные аварии, катастрофы). В связи с этим встает вопрос о сущности рисков, угроз и опасноcтей, грозящих всему живому, в первую очередь - человечеству.

В целом понятие риска можно определить как «риск - это ситуация с неопределенностью, которая может иметь несколько исходов», к категории «чистых рисков» относят ситуации, когда «один из возможных исходов будет неблагоприятным», кроме того на понятийном уровне принято, что риск включает в себя сочетание вероятности какого-либо события и/или последствий его наступления. С точки зрения социологических подходов, риск - это всегда ситуация выбора, например, между менее привлекательной, но более надежной стратегией, и более привлекательной, но менее надежной. Такая ситуация выбора складывается, например, при решении вопроса о строительстве атомных электростанций: более экономичных, гарантирующих энергетическую независимость, но и более опасных (кстати, теория риска как раз и получила развитие в ходе разработки оценок радиациионого и экологического рисков).

С проблемой риска связана также ситуация создания риска (например, ДТП как одна из ведущих причин смертей зачастую «создается» нетрезвостью водителей; риск ядерной катастрофы - самим строительством АЭС). Таким образом, создание риска представляет риск сам по себе. Один из эффективных способов решения проблемы «создания риска» заключается в такой оценке ситуации, чтобы «сценарий» включал непопулярные и невероятно высокие «угрозы» и/или «события-видения». Это вызывает страх, заставляющий людей стараться не создавать угрозы риска.

Понятия риск и угроза тесно связаны, однако различаются между собой. Угроза - это описание источника потенциальных опасностей и рисков, при этом ее вероятность трудно оценить для конкретных условий. Примерами угроз могут быть: природныле события и/или катастрофы (например, землетрясение, наводнение, цунами, извержение вулкана, лесные пожары), экологические катастрофы (например, глобальное изменение климата), техногенные катастрофы (ядерная угроза).

Onacность - это возможность возникновения обстоятельств, которые могут повлиять на сложную экологическую или социальную систему таким образом, что это приведет к ухудшению или невозможности ее функционирования и развития. Опасность, как и угроза, - это объективньле обстоятельства: наступление или вероятность наступления нежелательных событий. Риск же связан с деятельностью человека (например, при создании рисков).

Особая ситуация складывается и в отношении такого субъективного морально-психологического фактора, как восприятие рисков. Угрозы голода и нищеты, которые определяли экономико-политическую динамику в период становления и развития индустриального общества, воспринимались непосредственно. Человеку не нужно было спрашивать эксперта о реальности собственного голода и о том, что необходимо делать для избавления от него. Для этого не нужны измерительные приборы, сбор статистических данных, их подтверждение. Иная ситуация складывается в обществе риска. Каждый человек оказывается зависимым от чужого знания. «Жертвы становятся некомпетентными в деле, касающемся их собственной жизни. Они утрачивают значительную часть суверенного знания. Вредное, таящее в себе угрозу, враждебное притаилось повсюду, но судить о вредности и полезности сами они не в состоянии и потому вынуждены пользоваться гипотезами и методами чужих производителей знаний», - пишет У. Бек [1].

В результате риски несут с собой двойной шок: шок, непосредственно связанный с угрозой, и шок вследствие собственной беспомощности, неспособности ни разглядеть угрозу, ни уберечься от нее. Человек вновь оказывается зависимым от науки - без нее он не способен воспринять риск, даже если этот риск является следствием деятельности самих ученых (например, риск использования ГМО). Двойной шок оказывается чреват парадоксальными антропологическими последствиями. В результате «шоковой терапии» сознание человека раздваивается, и мир, в котором он живет, также оказывается раздвоенным: это реальный наблюдаемый мир и мир невидимый, но страшащий своим присутствием.

«Цивилизационные угрозы ведут к возникновению своеобразного "царства теней", ...которое таится за видимым миром и угрожает жизни человека на этой земле. Сегодня мы имеем дело не с духами, которые прячутся в вещах, мы подвергаемся "облучению", глотаем "токсические соединения", нас наяву и во сне преследует страх перед "атомным холокостом"... Непосредственному наслаждению радостями жизни, простому существованию пришел конец. Всюду корчат рожи вредные и ядовитые вещества, бесчинствуя, словно черти в средневековье. Люди перед ними полностью беззащитны. Дышать, пить, есть - значит повсюду сталкиваться с ними». Причем каждое из них имеет «свои собственные отношения вражды со специальными противоядиями, свои ритуалы уклонения, формулы заклинания, свои предчувствия и уверенность в своих возможностях».

Например, этикетка на продукте питания или сигаретах одновременно и признает угрозу, указывая на содержание «вредных веществ» (соли, сахара, никотина и др.), и заклинает («заговаривает») ее, демонстрируя, что «все под контролем» [1]. 
В Декларащии РИО-92 говорится: «Никогда в истории от того, что вы делаете или не делаете, так много не зависело для вас самих, для других, для ваших детей, для ваших внуков, для жизни во всем многообразии ее форм». Риски, возникающие при расщеплении атомного ядра, использовании методов генной инженерии, клонировании или строительстве новой АЭС, становятся синонимом глобальной угрозы для всего человечества, угрозой самоуничтожения жизни на Земле. Глобализация рисков объединяет человечество и заставляет искать общий морально значимый ответ.

\section{Обеспечение экологической безопасности в Беларуси}

На основе конщепции риска в Республике Беларусь сформирована комплексная система экологической безопасности, включающая организационную (нормативно-правовую базу) и управленческую инфраструктуры, системы мониторинга окружающей среды, подготовки кадров, образования, научного обеспечения, информирования населения. Созданный механизм, обеспечивающий безопасность в экологической сфере, в целом вполне эффективен, хотя и требует совершенствования с учетом новых угроз и возможностей экономики страны.

Согласно Концепции национальной безопасности Республики Беларусь [4], экологическал безопас$\boldsymbol{\mu o c m b}$ - это состояние защищенности окружающей среды, жизни и здоровья граждан от возможного вредного воздействия хозяйственной или иной деятельности, чрезвычайных ситуаций природного и техногенного характера. Ее обеспечение является обязательным условием устойчивого развития страны и призвано реализовывать конституционное право граждан на благоприятную окружающую среду.

В целом степень защищенности населения и окружающей среды от техногенных и природных воздействий приемлема для нынешнего этапа социально-экономического развития Беларуси. Вместе с тем современный уровень экологической безопасности в стране не вполне соответствует требованиям устойчивого развития. Потенциальную опасность для экологической безопасности Беларуси представляют такие антропогенные факторы, как высокий уровень индустриального развития с большой долей химической промышленности, разветвленная сеть магистральных нефтепроводов и газопроводов, интенсивное сельское хозяйство, ограниченное использование современных природозащитных и ресурсосберегающих технологий, повышенный уровень износа основных производственных средств, наличие обширной зоны радиоактивного загрязнения, слабое развитие правовых и экономических механизмов экологического регулирования природопользования, недостаточно сформировавшееся экологическое сознание населения.

Потенциальные или реально существующие угрозы нанесения ущерба экологической безопасности Беларуси академик НАН Беларуси В. Логинов подразделяет на внешние и внутренние [5].

К внешним он относит: глобальные изменения климата и увеличение частоты опасных погодных явлений, опасность разрушения стратосферного озонового слоя, способного привести к усилению вредного для здоровья людей ультрафиолетового излучения, падение урожайности сельскохозяйственных культур из-за увеличения содержания приземного озона, рост масштабов глобального разрушения природных экосистем, трансграничный перенос на территорию Беларуси загрязняющих веществ воздушными и водными потоками, проникновение инвазивных видов животных и растений из сопредельных стран, возникновение эпидемий в популяциях диких животных в странах, связанных с Беларусью их миграционными потоками, размещение атомных электростанций и иных опасных объектов в Беларуси и на сопредельных с ней территориях.

Внутренними факторами являются: масштабное радиоактивное загрязнение территории страны, возникновение проблем транспортировки ядерного топлива и обращения с отходами ядерного топлива в связи со строительством АЭС в Беларуси, повышенные уровни выбросов загрязняющих веществ, появление территорий с высокими уровнями химического и биологического загрязнения почв, вод, растительности, увеличение использования местных видов топлива (торфа, бурых углей, растительных отходов, в перспективе - горючих сланцев), незавершенность в производственном комплексе страны технологических циклов, допускающая образование больших объемов отходов, повышенное использование химических удобрений в сельском хозяйстве, концентрация животноводства на крупных комплексах; использование экологически несовместимых технологий природопользования в сельском и лесном хозяйстве, высокая концентрация в Беларуси опасных объектов (химических предприятий, нефте- и газопроводов, захоронений высокотоксичных и радиоактивных отходов и др.), их размещение вблизи жилых зон; повышенная степень износа основных производственных средств этих объектов; распространение на территории страны опасных природных явлений (метеорологических, гидрологических, геологических, биологических), способных вызвать стихийные бедствия (засухи, заморозки, ураганы, пожары в лесах и на торфяниках, наводнения, эпидемии и др.). Все это создает угрозу ухудшения качества воды, атмосферного воздуха, почв, растений, сельскохозяйственной продукции, что может привести к ухудшению качества жизни населения, уменьшению продолжительности жизни, увеличению заболеваемости и смертности, экономическим потерям и снижению темпов экономического развития страны. 
Стратегия национальной безопасности Республики Беларусь базируется на концепции приемлемого рис$\kappa a$, допускающего такую величину риска, которая по техническим, экономическим и технологическим параметрам возможна как некоторый компромисс между уровнем безопасности и возможностями его достижения. Национальная безопасность в экологической сфере обеспечивается в Республике Беларусь развитием международного сотрудничества в области охраны окружающей среды и правового разрешения экологических проблем транснационального характера; повышением достоверности оценок и прогнозов состояния природной среды, изменений климата, опасных погодных и климатических явлений; адаптацией отраслей экономики к их изменениям; сокращением выбросов в атмосферу парниковых газов и др. [6]. Выполнение этого комплекса мер, реализация названных механизмов призваны обеспечить конституционное право граждан на благоприятную окружающую среду как необходимое условие устойчивого развития и обеспечения экологии человека.

Однако на фоне безусловных успехов по обеспечению устойчивого развития все чаще и громче стали звучать тревожные сигналы о разрушительных опасностях и угрозах существованию человечества и природы со стороны экологических катастроф и катаклизмов. Постепенно стало очевидно, что это не трагические случайности, за которыми мы следим со страхом, но и с некоторым удовлетворением: «Слава Богу, что это не у нас: у нас такого быть не может». Пора осознать, что человечество вступило в новый, еще более опасный этап общества риска, для которого характерны новые объективные реалии - от разнообразных и все более трагичных проявлений глобального изменения климата на макроуровне до пандемии COVID-2019, которая реализуется через проникновение в отдельный человеческий организм новой формы вируса на микроуровне. Это поставило вопрос о необходимости обращения к новой парадигме постгуманизма: к дополнению оптимистической ориентации на устойчивое развитие более пессимистической, но и более актуально-реалистичной стратегией выжсивания, которой соответствует новая форма экологической этики - экстремальная этика.

На постсоветском пространстве научный анализ стратегии выживания в конце прошлого века полно и последовательно начал осуществляться профессор Т. Цырдей в Молдове, в Государственном медицинском и фармацевтическом университете им. Н. Тестемицану в Кишиневе.

\section{4. Экологическая этика как методологическое основание устойчивого развития и стратегии выживания}

Необходимость заботы обо всех живых организмах и окружающей среде в целом (как одна из важнейших задач глобальной и социальной биоэтики) вызвала к жизни экологическую этику, вырабатывающую и предлагающую обществу новые нравственные нормы поведения людей как в «человеческих», так и «нечеловеческих» ситуациях.

Экологическая (энвайронментальная) этика - система принципов и норм в отношениях человека с природой, основанных на восприятии природы как морального партнера (субъекта), признании равноправия и равноценности всего живого, внутренней ценности природы, уважении ее прав и ограничении прав человека. Экологическая этика выступает в качестве методологического основания обеспечения устойчивого развития и стратегии выживания, чему способствуют ее основные принципы, регулирующие общение и поведение человека в природе.

К общим принципам экоэтики, призванным обеспечивать биобезопасность человечества в обществе риска, относят шесть принципов:

- принцип биоразнообразия, утверждающий ценность и необходимость сохранения разнообразия видов как одного из проявлений богатства природы;

- принцип поддержания устойчивости биосферы, констатирующий приоритетное значение сохранения биосферы в целом как более важного, чем сохранение любой индивидуальной жизни, вида или экосистемы (данный принцип лежит в основе концепции устойчивого развития);

- принцип экологической справедливости, настаивающий на равном распределении между людьми права на экологическую безопасность (при этом каждому вменяется ответственность за ее сохранение);

- принцип предосторожности, требующий при разработке экологической политики в первую очередь принимать во внимание наиболее опасный из возможных вариантов развития событий, который включает: а) необходимость учета уязвимости природной среды, б) недопустимость превышения ее «пределов прочности», в) недопустимость противоречий с естественными закономерностями, чтобы не нарушать их сложных взаимосвязей и не вызывать необратимых процессов;

- принцип общего достояния природных ресурсов, представляющий планету Земля как целостность, в соответствии с чем люди должны нести равную ответственность за окружающую среду и природные ресурсы, поскольку их истощение будет иметь опасные последствия для всех людей - как ныне живущих, так и будущих поколений;

- принцип презумпции опасности, вытекающий из принципа уважения к жизни и принципа предосторожности - он выражается в практическом требовании: те, кто предпринимает действия, имеющие опасные последствия для окружающей среды и людей, обязаны доказать их безопасность [7]. 
В контексте обеспечения экологической безопасности и сохранения биоразнообразия не менее значимы следующие теоретические принципы экоэтики:

- принцип субъект-субъектных отношений человека и природы, вытесняющий традиционные отношения, в которых природа выступает для человека как объект воздействия и использования, и заменяющий их принципиально иными, необходимыми для равноправного диалога человека и природы, которая выступает как иной субъект;

- принцип уважения ко всем формам жизни, утверждающий ценность жизни и моральное значение каждого живого существа безотносительно интересов человека, независимо от его «полезности» или «вреда»; это принцип благоговения перед жизнью, требующий «относиться с благоговением к каждому живому существу и уважать его как собственную жизнь», говоря словами А. Швейцера, который утверждал: «Я - жизнь, которая хочет жить... среди жизни, которая хочет жить»;

- экологический императив - по Н. Моисееву это принцип, предъявляющий требования-«повеления» людям: учитывать одинаковую уязвимость человека и природной среды; не допускать превышения их «пределов прочности»; не вступать в противоречие с природными закономерностями; исключить из обихода «старые» принципы полезности и целесообразности, заменив их новыми - «этико-биоэкологизированными».

Эти принципы глобальной экоэтики порождают ряд «открытых» проблем, норм и регулятивов, также носящих неоднозначный и дискуссионный характер.

Прежде всего, это необходимость решить до сих пор нерешенную проблему автономии природных ценностей: следует ли признать независимость и внутреннюю самоценность природных объектов, или их ценность определяется в зависимости от человека, его потребностей и интересов? С точки зрения глобальной биоэтики, экосистемы должны быть признаны самостоятельными моральными субъектами, которые обладают внутренней неотъемлемой ценностью. Человек не вправе решать с позиции пользы и целесообразности вопрос о ценности или праве на жизнь того или иного вида; он должен заботиться о сохранении всех видов и объектов природы, не допуская потерь в биоразнообразии. Тем самым накладывается нормативнонравственный мораторий на обращение с природой как с вещью и ресурсом. Только самоценность природных систем может быть основанием современной экоэтики.

Понимание того, что исключительно человекоцентристские цели в рамках антропоцентрического подхода не могут и далее оставаться единственным принципом экологической этики и политики человечества. Поэтому решение проблемы самоценности природы должно проходить по линии водораздела между антропоцентризмом и не-антропоцентризмом; человечество должно окончательно (и реально) отказаться от антропоцентризма, считающего Человека высшим критерием в шкале ценностей, высокомерно и эгоцентрично ставя его над Природой, и взять на вооружение не-антропоцентристский подход, выдвигающий на первый план гармоничное и равноправное сообщество людей и других живых и неживых компонентов природы.

Одним из проявлений не-антропоцентристского подхода выступает нравственно-понимающее отношение к природе на основе признания «одухотворенности» Живого. Проявляется оно в стремлении понять Живое, его чувствования и переживания. Для такого со-чувствия, со-страдания необходимо, чтобы Живое «не-человеческий субъект» признавалось источником отношений, равным субъекту человеческому. Подобное отношение к природе возможно только при установлении субъект-субъектных отношений между человеком и природой, когда природные явления воспринимаются человеком как «свое Иное», как Иной субъект.

Способность испытывать, по требованию О. Леопольда, чувство времени, обращенность в будущее, предполагающие заботу о природных условиях существования будущих поколений, на основе специфических моральных принципов, таких как принцип хронологической объективности, «долг перед потомками», нормы-императивы «диалога с будущим», которые должны лежать в основе наших обязательств перед будущими поколениями, имеющими право на достойную жизнь.

Рассмотренные принципы, нормы и императивы в совокупности составляют концептуальные основания экологической этики [7]. Их часто называют «десятью эколого-этическими заповедями»:

1. Высшую ценность представляет гармоничное развитие человека и природы, природа и человек элементы единой системы.

2. Природное изначально самоценно, имеет право на существование независимо от пользы или вреда для человека.

3. Человек - один из членов природного сообщества, а не его собственник.

4. Природа - полноправный субъект взаимодействия с обществом.

5. Иерархической картины мира не существует; человек не обладает какими-либо особыми привилегиями: разумность налагает на него лишь определенные обязанности по отношению к окружающей природе.

6. Характер взаимодействия человека с природой определяется экологическим императивом: правильно и разрешено только то, что не нарушает существующее в природе экологическое равновесие.

7. Цель взаимодействия человека с природой - удовлетворение потребностей как человека, так и всего природного сообщества; их взаимодействие должно сменить воздействие человека на природу. 
8. Этические нормы и правила равным образом распространяются как на взаимодействие между людьми, так и на взаимодействие с миром природы.

9. Развитие природы и человека - это процесс коэволюции, взаимовыгодного функционирования.

10. Деятельность по охране природы продиктована необходимостью сохранить природу ради нее самой.

Таким образом, экологическая этика, вырабатывающая новые нравственные нормы поведения личности как в социуме, так и по отношению к природной среде, благодаря своей универсальности становится не только необходимым элементом глобальной биоэтики, но и фактором обеспечения экологической безопасности на основе нравственно-экологического образования, воспитания и просвещения.

Выделяют два подхода к проблеме уменьшения экологического риска и обеспечению безопасности. Первый, все еще наиболее распространенный - борьба не с причинами возникновения сверхриска, а с его последствиями. Это «латание дыр» - занятие необходимое, но не устраняющее источник неустойчивости. Второй подход - анализ и устранение причин сверхриска - основывается на экологической и биоэтической культуре, на актуализации, развитии и внедрении представлений о системности, целостности воспроизводства жизни, объективной, неустранимой зависимости жизни социума от состояния живой и неживой природы [3].

Необходимое повышение уровня биобезопасности может быть достигнуто лишь при изменении всех форм соииальной активности на основе экологического сознания. Авторы книги «Путь к экологической культуре» так характеризуют основные из этих форм [8]. Во-первых, для повышения уровня биобезопасности необходима информация - не только о рисках, кризисах и катастрофах, но и о состоянии всех экологических подсистем. Во-вторых, эту информацию нужно превратить в знание - т.е. систематизировать ее, выделить основное и второстепенное, традиционное и новое. В-третьих, перевести знание в убеждения, принципы поведения, что происходит под воздействием системы образования. $B$-четвертых, в обеспечении минимального уровня экологического риска и биобезопасности человечество должно опираться на нормы права, принципы эко- и биоэтики.

Экологическая культура - это не еще одно направление или аспект культуры, а новое качество культуры, отражение целостного мира на основе его практического, интеллектуального и духовного постижения. В экологической культуре картина мира предстает во всем многообразии как рационального, так и духовного воплощения; в отображении мира участвуют не только наука, но все без исключения языки культуры: миф и религия, наука и искусство, опыт практического освоения мира и, конечно, опыт духовных исканий и откровений.

Первым важным шагом на этом конструктивном пути является объективная оценка ситуации, в которой разного рода девиации, нарушение норм общежития принимают тотальный характер. И дело здесь не только в том, что люди несовершенны, но и в том, что нормы утратили свой некогда присущий им потенциал поддержания порядка, а «старый» порядок себя исчерпал. Следующий шаг - определение причины подобного состояния, невозможное вне экологического подхода, без анализа социума как подсистемы глобальной социо-природной системы. В стремлении обособиться, утвердить свою самостоятельность общество завело себя в тупик. Выход может заключаться в принятии нового «общественного договора».

Новый «договор» может быть заключен на принципиально иных основаниях, чем «старый». Генеральную цель социума он должен видеть не в закреплении его самостоятельности и «независимости» от природы, но, напротив, в коадаптации, сближении с природой. При этом важнейшим условием жизнеспособности подобного «договора» должна стать ведущая роль духовных иенностей и вспомогательная роль иенностей материальных. Именно такая иерархия позволит преодолеть охватившее общество тотальное чувство страха и обеспечит сохранение, развитие и биобезопасность глобальной социоприродной экосистемы, ибо сегодня мир ждет совсем другого отношения, - отношения к себе как к целому, безусловно ценному, драгоиенному для каждого человека [8].

\section{Экстремальная этика в обществе экологического риска}

Термин «экстремальная этика» введен выдающимся современным этиком и философом М. Н. Эпштейном [9] совсем недавно, в связи с пандемией COVID-2019, которая поставила перед человечеством множество этических проблем - как долгосрочных, стратегических, нуждающихся в серьезной умозрительной рефлексии, так и тактических, насущных, которые приходится решать каждый день и даже каждую минуту. Например, медицинская сортировка, или триаж, - отбор тех больных, которым нужно в первую очередь оказывать помощь в условиях дефицита врачей и оборудования. Как решить, кого спасать, кому предоставить прибор искусственного дыхания, а кого обречь на смерть?

Моральный долг врача, как он обычно понимается, обращен к каждому отдельному индивиду: сделать все необходимое для его исцеления. Это отношение один на один. Но когда больных сотни и тысячи, как во время войн и эпидемий, начинает действовать другая, экстремальная этика, которая кажется чудовищной с точки зрения обычных нравственных норм. Приходится сознательно и целенаправленно оставлять одних агонии и смерти, чтобы излечить других. В таких условиях врач принимает на себя образ Господа 
Бога и полностью подменяет его в праве выбора - кому жить, а кому умереть. Но какими критериями он должен руководствоваться?

Вместе с тем, кроме ситуативного принятия решения как «руководства к действию», выдвигаются проблемы глобально-стратегического плана: как сигнал к пересмотру сложившихся, устоявшихся и таких привычных мировоззренческих подходов - того, что принято называть научными парадигмами. Смена парадигм - это сущность научной революции, зачастую переворачивающей представление о мире и меняющей научную картину мира. Такими сменами научных парадигм можно считать открытие атомной структуры, генома живой материи, новые феномены в радиобиологии (эффект свидетеля и геномная нестабильность) и др.

В сфере экологического научного знания методолого-мировоззренческим революционным переворотом стало появление в 1970-х гг. глобальной биоэтики и смена антропоцентрической парадигмы в отношениях человека и природы на не-антропоцентрическую [эко(био)центрическую], которая ставит во главу угла не человека, которому должна «подчиняться» и «служить» вся природа - живая и неживая. Содержанием и целью глобальной биоэтики выступает скромное осознание человеком себя как части живого и его забота: обо всех ныне живущих людях, о правах и интересах будущих людей, обо всех живых организмах, об окружающей среде и биосфере в целом. Эта новая не-антропоцентрическая энвайронментальная парадигма поначалу воспринималась как красивая пост-гуманистическая декларация, с которой все умозрительно были согласны, но которая никого ни к чему не обязывала. И приняв эту декларацию как красивую сказку из «прекрасного далеко», мы продолжали, как ни в чем не бывало, относиться к природе и ее проявлениям по-старому - с антропоцентристских позиций управления, использования, борьбы, а не с позиции сотрудничества, взаимодействия, коэволюции. Мы забывали о необходимости субъект-субъектных отношений между человеком и природой, не задумываясь о том, что это значит; мы не затрудняли себя нравственно-понимаюшим отношением, со-чувствием и со-страданием к ней; нам по-прежнему чужд «нравственно-экологический императив» и «благоговение перед жизнью».

«В развращенности века каждый из нас принимает то или иное участие. Одни вносят свою долю предательством, другие - беспечностью, безбожием, насилием, алчностью, жестокостью; короче говоря, - каждый тем, в чем он сильнее всего; самые же слабые добавляют к этому глупость, суетность, праздность», - писал Мишель Монтень. Сегодня людям предстоит менять себя, чтобы вернуть гармонию с миром и обеспечить собственную безопасность. Задача сохранения жизни на планете, устойчивое развитие как способ существования «духовного общества» не могут быть обеспечены в рамках прежней парадигмы общественного развития [3].

Людям предстоит вспомнить, что по своей сути экологическая этика - это этика ненасилия, распространенная на отношение человека к природе. И так же, как в человеческих отношениях, эффективность этики на протяжении тысячелетий была весьма низкой, но обращение к ней - было единственным шансом минимизации зла (что человечество начало осознавать лишь сегодня), так и в отношениях с природой: отказ от сознательного причинения ей зла, отказ от насилия по отношению к природным объектам - это «мост в будущее» (В. Р. Поттер) - единственная возможность выживания для человечества - даже с позиций антропоэгоизма.

Вместе с тем только в экстремальных ситуациях (как, например, сейчас - в кризисной ситуации с изменением климата или появлением коронавируса) мы начинаем понимать, что отношения с природным миром не могут бесконечно строиться на борьбе, что борьба эта бесперспективна, потому что объективные природные условия существования, независимые природные катаклизмы - они сильнее и могущественнее человечества - этой временной формы существования материи. И тогда встает вопрос о том, что в экстремальных условиях человечество должно, наконец, учиться использовать преимущество, данное ему природой - разум - с тем, чтобы понять: просто не-антропоцентризма уже недостаточно. $B$ экстремальных условиях человек должен открывать для себя и учиться пользоваться экстремальной этикой, парадоксальной, но необходимой, которая требует:

- признания неисчерпаемых возможностей и прав природы на самомодификацию;

- защиты прав человека и природы в экстремальных условиях;

- анализа возможных рисков и уязвимости населения; защиты групп населения, особенно уязвимых в экстремальных условиях и защиты прав будущих поколений;

- регуляции поведения населения в экстремальных условиях;

- обязательного применения принципа предосторожности и презумпции опасности, непосредственно связанных с экстремальными условиями.

Более 100 лет назад, в начале XX века умами российской интеллигенции завладела знаменитая молитва святого Иоанна Кронштадтского: «Господи! Дай мне силы, чтобы изменить то, что возможно, дай мне мужество вынести то, что изменить невозможно, и дай мне мудрость, чтобы отличить одно от другого». Эта молитва - как наказ людям принимать мудрые решения в условиях неопределенности, опасностей и рисков. В наше время в условиях глобального экологического кризиса эти слова обретают особую актуальность.

И поэтому представляется весьма разумной и рациональной позиция ЮНЕСКО, направленная на выработку эффективной политики по сохранению человечества в условиях глобального изменения климата, основными задачами которой должны стать: 
- поиск и разработка путей и методов противостояния этим изменениям;

- адаптация к ним человеческого сообщества;

- соблюдение при решении этих задач прав человека и природы.

Обратите внимание: основные задачи - не борьба с изменениями климата, а «поиск и разработка путей и методов противостояния» им, «адаптация к ним человеческого сообщества». Независимо от того, носят ли глобальные экологические изменения антропо-техногенный или стихийно-природный характер, человечество должно незамедлительно искать методы и средства диалога с природой и быть готовым к любым природным и климатическим катаклизмам, угрозам и рискам. Мы считаем, что такой подход является справедливым по отношению именно к любым природным катаклизмам, угрозам и рискам, которые упорно возникают (и скорее всего, будут возникать и дальше) на планете Земля. А это требует сменьl ментальной парадигмы, переосмысления принципов взаимоотношений человека и природных условий. Сегодня это требование справедливо и по отношению к ситуации, связанной с пандемией COVID-19.

Как ни кощунственно это звучит, но мы считаем, что бессмысленно говорить о «борьбе» с вирусом. Ведь он не хочет зла человеку, он реализует, как может, свое стремление к выживанию, более того, он «заинтересован» в человеческой жизни (а не смерти). Безусловно, это не означает, что мы должны его «холить и лелеять» согласно принципу «благоговения перед жизнью». Нет, человечество должно противостоять ему, минимизируя его смертельный вред для человека, и, вместе с тем, искать пути адаптации к этой и идущим за ним следом другим формам вирусных инфекций. Ведь нам, скорее всего, придется жить вместе с ними и, возможно, они останутся надолго (если не навсегда).

В качестве возможности и продуктивности такой адаптации можно рассматривать радикальное изменение отношения к статусу ВИЧ и людям ВИЧ-инфицированным, благодаря достижениям современной медицины и генетики. Сегодня люди с «ВИЧ-неопределенной нагрузкой» больше не рассматриваются как обреченные, как источники инфекции. Они могут вести обычный образ жизни и дожить до глубокой старости. А ведь совсем недавно ВИЧ был источником стигматизации и дискриминации, к ВИЧинфицированным относились в обществе как к прокаженным, настаивая на их глубокой изоляции.

Еще одно «этико-кощунственное» замечание относительно COVID-19 и других пандемий в истории человечества, свидетельствующее о необходимости пересмотра традиционных парадигм, также носит неоднозначный и небесспорный характер. Не будучи ни в коей мере сторонниками неомальтузианства, мы готовы призвать наших читателей подумать над справедливостью Закона народонаселения Мальтуса, который он считал вечным, незыблемым законом природы. По его мнению, народонаселение Земли растет в геометрической прогрессии, тогда как средства существования растут в арифметической прогрессии. И чем больше население, тем меньше обрабатываемой земли остается на одного человека. Поэтому в силу действия закона убывающего плодородия возникает тенденция отставания роста продовольственных ресурсов от роста населения. В последнее время получили активное распространение такие концепции неомальтузианства, как теория оптимума населения (Г. Браун, Дж. Боннер), утверждения Г. Тейлора и П. Эрлиха о росте народонаселения как единственной причине экологического кризиса и т. п. В этих условиях выдвигаются довольно циничные (но в то же время весьма логичные) предположения, что экологические и др. катастрофы, в том числе эпидемии и пандемии являются формой саморегуляции баланса народонаселения и средств существования. В качестве подтверждения приводятся исторические примеры резкого скачка развития Европы после средневековых эпидемий чумы и холеры.

Природа не терпит пустоты и если освобождается некая экологическая ниша, то она немедленно заполняется, и это положение вполне справедливо и в ситуации с вирусами: мы успешно справились с гепатитом A, но ему на смену пришли риски заражения гепатитами В и С, и т.д. Это, в частности, доказательство того, что «полная победа» над конкретным видом вирусов не избавит от появления более опасных новых форм. В связи с этим представляется справедливой позиция Ганди, который считал, что популяционный иммунитет возможен только в условиях постоянного (и неизбежного) контакта с возбудителями.

В этих условиях речь идет об объективной необходимости и неизбежности смены этических парадигм, становящихся экстремальной этикой в экстремальных условиях. Или, по крайней мере, о необходимости философской рефлексии по поводу смены этих парадигм. Методологической основой морального выбора и разрешения складывающихся здесь ситуаций выступают такие философские системы, как утилитаризм и эгалитаризм. Для первой высшая цель - дать наибольшее «количество здоровья» наибольшему числу людей. Одни и те же ресурсы, если распределить их между «излечимыми», могут продлить жизнь большего числа людей на большее число лет. Вторая система требует предоставить всем равные условия для выживания и благоденствия, а значит, проявить больше заботы о тех, кто больше всего нуждается, то есть выровнять доступ к благам медицины за счет преимущественной помощи наименее защищенным, компенсируя лечением их физическую недостаточность.

С точки зрения утилитаристской этики медицинская полезность, то есть объем продленной физической жизни на единицу затраченных ресурсов, может, кроме того, дополняться социальной полезностью. 
Поэтому в первую очередь помощь должна оказываться тем, кто сам оказывает помощь, - врачам, сестрам, санитарам, а также работникам спасательных служб. Проблема эта уже неоднократно озвучивалась (в разных странах сообщалось о высокой заболеваемости COVID-2019 среди медиков). Но, к сожалению, мало кто озадачивался тем, что поскольку они спасают других людей, они заслуживают приоритетного лечения, которое тем самым умножит благотворное действие медицины: вылечишь врача - вылечишь его будущих пациентов. Если же социальную полезность рассматривать еще шире, не ограничиваясь медициной и физическим выживанием, но имея в виду благо цивилизации и всего человечества, то видный политик, ученый, инженер, филантроп, артист - люди, доказавшие свою полезность обществу, также должны попасть в приоритетную группу спасаемых, поскольку, помогая им, мы обеспечиваем социальное, экономическое, научно-техническое, культурное развитие цивилизации в поствирусную эру. Очевидно, именно в этом вопросе утилитаризм особенно остро противостоит эгалитаризму, который требует в первую очередь спасать слабых, пренебрегая сильными и здоровыми, которые сами о себе позаботятся. Утилитаризм, напротив, исходит из того, что здоровым (в том числе молодым) и сильным (в том числе профессионально полезным и социально значимым) нужно помогать в первую очередь, поскольку от их выживания зависит благополучие всех остальных. Поэтому усилия медиков должны быть направлены на укрепление тех приоритетов, которые обозначены в самом бытии природы и общества, а не применять их в пользу слабых и бедных.

Какая система более справедлива - ориентированная на самых сильных или самых слабых, самых нужных или самых беззащитных и уязвимых?

В самом начале пандемии всемирно известный современный философ Ю. Хабермас написал: «Никогда еще не было так много знаний о нашем невежестве и о неизбежности действовать и жить в условиях неопределенности». Возможно, он прав?

\section{Библиографические ссылки}

1. Бек У. Общество риска. На пути к другому модерну. Москва: Прогресс-Традиция; 2000. 384 с.

2. Йонас Г. Принции ответственности. Опыт этики для технологической циивилизации. Москва: Айрис-Пресс; 2004.480 с.

3. Тищенко ПД. Концепция общества риска как отражение современной экологической ситуации. В: Мишаткина ТВ, Кундас СП, редакторы. Основы экологической этики. Минск: МГЭУ им. А.Д. Сахарова; 2008. с. 145-153.

4. Концепция национальной безопасности Республики Беларусь: утверждена Указом Президента Республики Беларусь № 575 от 9 ноября 2010 г. [Интернет; процитировано 11 февраля 2021 г]. Доступно по: http://www.pravo.by/webnpa/text. asp?RN=P31000575.

5. Логинов ВФ. Против спектра угроз. Экологическая безопасность Беларуси. Беларуская думка, 2011;3:68-75.

6. Александрович ЯМ, Богданович АВ, Крюков ЛМ и др., редакторы. Национальная стратегия устойчивого социальноэкономического развития Республики Беларусь на период до 2020 г. Минск; 2004 [Интернет]. [Процитировано 19 августа 2020]. Доступно по: https://un.by/images/library/thematic-publications/sustainable-development/OON sMall Rus.pdf.

7. Мишаткина ТВ, Мельнов СБ, редакторы. Социальная биоэтика сквозь призму глобальной биоэтики. Минск: МГЭИ им. А. Д. Сахарова; 2018. 518 с.

8. Мазур ИИ, Козлова ОН, Глазачев СН. Путь к экологической культуре. Москва: Горизонт; 2000. 194 с.

9. Эпштейн МН. Будущее гуманитарных наук: Техногуманизм, креаторика, эротология, электронная филология и другие науки ХХІ века. Москва: РИПОЛ Классик; 2019. 239 с.

\section{References}

1. Beck U. Risk Society: Obshchestvo riska. Na puti k drugomu modernu [Towards a New Modernity]. Moscow: Progress-Traditsiya; 2000. 384 p. Russian.

2. Jonas H. Printsip otvetstvennosti. Opyt etiki dlya tekhnologicheskoy tsivilizatsii [the imperative of responsibility: in search of an ethics for the technological age]. Moscow: Iris-Press; 2004. 480 p. Russian.

3. Tishchenko PD. Concept of Risk Society as Reflection of Modern Ecological Situation. In: Mishatkina TV, Kundas SP, editors. Foundations of Ecological Ethics. Minsk: ISEU named after A.D. Sakharov; 2008. p. 145-153. Russian.

4. National Security Concept of the Republic of Belarus. Approved by Presidential Decree №575 of 2010 November 9. [Internet; cited 2021 February 11]. Available from: http://www.pravo.by/webnpa/text.asp?RN=P31000575. Russian.

5. Loginov VF. Against Spectre of Threats. Ecological Security of Belarus. Belaruskaya dumka. 2011;3:68-75. Russian.

6. Alexandrovich YaM, Bogdanovich AV, Kryukov LM et al., editors. National Strategy for Sustainable Socio-Economic Development of the Republic of Belarus Up To 2020. Minsk, 2004. 204 p. [Internet; cited 2020 August 19]. Available from: https://un.by/images/ library/thematic-publications/sustainable-development/OON sMall Rus.pdf. Russian.

7. Mishatkina TV, Melnov SB., editors. Sotsial'naya bioetika sk̄koz' prizmu global'noy bioetiki [Social Bioethics Through the Lens of Global Bioethics]. Minsk: International Sakharov Environmental Institute of the Belarusian State University; 2018. Russian.

8. Mazur II, Kozlova ON, Glazachev SN. Put'k ekologicheskoy kul'ture [Towards Ecological Culture]. Moscow: Horizont; 2000. 194 p. Russian.

9. Epstein MN. Budushcheye gumanitarnykh nauk: Tekhnogumanizm, kreatorika, erotologiya, elektronnaya filologiya i drugiye nauki XXI veka [Future Humanities: Techno-Humanism, Creatorics, Erotology, Electronic Philology and other Sciences of the 21st Century]. Moscow: RIPOL Classik; 2019. 239 p. Russian. 